\title{
Medium-term and long-term in vitro conservation and safe international exchange of yam (Dioscorea spp.) germplasm
}

\author{
Bernard Malaurie ${ }^{1}$ \\ GeneTrop - Unité de Génétique et d'Amélioration des Plantes - Centre ORSTOM** - 911 avenue Agropolis - BP. 5045 -F. 34032. Montpellier Cedex 1, \\ France. \\ Tel: Bureau (33)-- 467416244 \\ Tel: Standard (33)-- 467416100 \\ Fax: (33)-- 467547800 \\ E-mail : Bernard.Malaurie@mpl.orstom.fr
}

Marie-France Trouslot

GeneTrop - Unité de Génétique et d'Amélioration des Plantes - Centre ORSTOM** - 911 avenue Agropolis - BP. 5045 -F. 34032. Montpellier Cedex 1, France. E-mail : Bernard.Malaurie@mpl.orstom.fr

\section{Julien Berthaud}

GeneTrop - Unité de Génétique et d'Amélioration des Plantes - Centre ORSTOM** - 911 avenue Agropolis - BP. 5045 -F. 34032. Montpellier Cedex 1, France. E-mail : Bernard.Malaurie@mpl.orstom.fr

\section{Mustapha Bousalem}

Laboratoire de Phytovirologie des Régions Chaudes (LPRC) - CIRAD-ORSTOM** - avenue du val de Montferrand - BP. 5035 -F. 34032 - Montpellier Cedex 1, France. E-mail : dubern@melusine.mpl.orstom.fr

\section{Agnès Pinel}

Laboratoire de Phytovirologie des Régions Chaudes (LPRC) - CIRAD-ORSTOM** - avenue du val de Montferrand - BP. 5035 -F. 34032 - Montpellier Cedex 1, France. E-mail : dubern@melusine.mpl.orstom.fr

\section{Jean Dubern}

Laboratoire de Phytovirologie des Régions Chaudes (LPRC) - CIRAD-ORSTOM** - avenue du val de Montferrand - BP. 5035 -F. 34032 - Montpellier Cedex 1, France. E-mail : dubern@melusine.mpl.orstom.fr

\section{http://www.mpl.orstom.fr}

Yam edible tubers feed million of peoples in the intertropical area, where they represent $12 \%$ of human feeding. However, as a vegetatively propagated crop, yam is seriously affected by an accumulation of pathogens. Establishing in vitro germplasm collection is a process that cleans the plants from all diseases but viruses. It gives a good control on the preservation of the yam genetic resources and facilitates international exchanges of healthy plant material.

Two kinds of in vitro germplasm preservation were considered : slow growth condition culture for midterm preservation, and cryopreservation using the encapsulation/dehydration technique for long-term preservation. Virus eradication was approached by meristem culture and chemo and thermotherapy. Production of virus-free plants was controlled by ELISA.
We succeeded in the introduction and maintenance of 20 yam species, under slow growth conditions. Cryopreservation was applied successfully on two edible yam species, Dioscorea. alata $\mathrm{L}$ and $D$. bulbifera L. Virus-free plants were obtained by meristem culture in $D$. cayenensis- $D$. rotundata complex and $D$. praehensilis. Indexation allowed the detection of different virus (poty-, potex-, badna- and cucumovirus), where the most important potyvirus was YMV.

Mid-term conservation of yam germplasm is used routinely, and from these conditions a direct acclimatization is possible. On the cryopreservation aspect, experiments are under way to apply the optimized protocol to genotypes which are more representative of the diversity, to insure a routinely use. More work can be conducted now on virus eradication,

\footnotetext{
${ }^{1}$ Corresponding author

** ORSTOM is now called IRD, Institut de Recherche pour le Developpement.
} 
based on knowledge accumulated on potyvirus diversity, on several tests available for yam indexing (ELISA, rt/PCR, monoclonal antibodies) and on new sanitation techniques.

Yam belongs to Dioscorea genus which has more than 600 species (Coursey, 1967) most of them distributed in the intertropical humid area. We will distinguish two types of yam: 1) medicinal yams, 2) edible yams and relatives. Medicinal yams concern about fifty species caracterized by their sapogenin content, which are steroidal components. For the edible yams and relatives, we will observe two groups: 1) domesticated species, 2) and wild species. For domesticated species we consider that forty to fifty species are occasionally used (Martin and Degras, 1978). From these only eleven are cultivated (Table 1). From the 11 cultivated, 6 represent an important part of feeding $(D$. alata, D. cayenensis-D. rotundata complex, D. bulbifera, D. dumetorum, D. esculenta, D. trifida), 3 are scattered in all the intertropical humid area (D. alata, D. bulbifera, D. esculenta), and yam belonging to the $D$. cayenensis- $D$. rotundata complex take place most of them in West Africa and some in the Caribbean area. The other yams are cultivated in their origin area (Degras, 1986).

Table 1 : Main edible species of yam

\begin{tabular}{|c|c|c|}
\hline Species $^{1}$ & Zone of origin & Zone of culture \\
\hline \multicolumn{3}{|l|}{ Enantiophyllum Section } \\
\hline D. alata $\mathrm{L}$. & South East Asia & Inter-tropical humid \\
\hline $\begin{array}{l}\text { D. cayenensis Lamk. } \\
\text { D. rotundata Poir. } \\
\text { complex }^{2}\end{array}$ & West Africa & $\begin{array}{l}\text { West \& Central Africa, and } \\
\text { Caribbean }\end{array}$ \\
\hline D. nummularia Lamk. & Indonesia, Oceania & $\begin{array}{l}\text { Indonesia, Oceania and } \\
\text { Micronesia }\end{array}$ \\
\hline $\begin{array}{l}\text { D. opposita Thunb. } \\
\text { D. japonica Thunb. } \\
\text { complex }^{3}\end{array}$ & $\begin{array}{l}\text { Temperate area from: } \\
\text { China, Corea, Taiwan } \\
\text { Japan }\end{array}$ & $\begin{array}{l}\text { Temperate area from: } \\
\text { China, Corea, Taiwan } \\
\text { Japan }\end{array}$ \\
\hline D. transversa $\mathrm{Br}$. & South Pacific & South Pacific \\
\hline $\begin{array}{l}\text { Lasiophyton Section } \\
D . \quad \text { dumetorum (Kunth) } \\
\text { Pax. }\end{array}$ & West Africa & West Africa \\
\hline D. hispida Dennst. & India, South-China, New Guinea & $\begin{array}{l}\text { India, South-China, New } \\
\text { Guinea }\end{array}$ \\
\hline D. pentaphylla L. & Himalaya and Oceania & Himalaya and Oceania \\
\hline $\begin{array}{l}\text { Combilium Section } \\
\text { D. esculenta (Lour.) Burk. }\end{array}$ & South East Asia & Inter-tropical humid \\
\hline $\begin{array}{l}\text { Opsophyton Section } \\
\text { D. bulbifera L. }\end{array}$ & South East Asia and Africa & Inter-tropical humid \\
\hline $\begin{array}{l}\text { Macrogynodium Section } \\
\text { D. trifida } \text { L. }\end{array}$ & Guyana, Amazonian basin & Caribbean \\
\hline
\end{tabular}

Sources: Malaurie et al. (1998a)

${ }^{1}$ Species have been regrouped in Section by Knuth (1924), completed by Burkill (1960)

${ }^{2}$ Grouping together species of $D$. cayenensis and D. rotundata in a Complex has been proposed by Ayensu and Coursey (1972), Martin and Rhodes (1978), Miège (1982)

${ }^{3}$ Grouping together species of D. opposita and D. japonica in a Complex has been proposed by Tanaka (1977).

Main edible species of yams are: 1) native of a continent, 2) and cultivated in the same continent, 3 ) or/and cultivated in an other. This observation implies very strong links to exchange problems. In Table 2, 36 countries have been observed by IBPGR in 1986 with Dioscorea germplasm. These countries are supposed to be concerned by an international exchange of yam germplasm. Some of them, 
have, in our knowledge, already developed in vitro germplasm collection.

Table 2 : Countries ${ }^{1}$ and geographic zones where yam collections have been observed

\begin{tabular}{|c|c|c|c|c|c|}
\hline Europe & West Indies & America & Pacific & Asia & Africa \\
\hline France $^{2}$ & Barbados * & Brazil $^{2}$ & Cook Islands & Bengladesh & Bénin \\
\hline \multirow[t]{9}{*}{ United Kingdom $^{2}$} & Cuba & Colombia & Fiji & India & Burkina Faso \\
\hline & Guadeloupe $^{2}$ & Costa Rica & Niue Islands & Indonesia & Cameroun \\
\hline & Jamaïca & Guatemala & $\begin{array}{l}\text { New } \\
\text { Calédoniaee }{ }^{2}\end{array}$ & Japan $^{2}$ & Ivory Coast $^{2}$ \\
\hline & $\begin{array}{l}\text { Saint- } \\
\text { Dominique }\end{array}$ & Mexico & $\begin{array}{l}\text { Papua } \\
\text { NewGuinea }\end{array}$ & Malaisia & Ghana \\
\hline & $\begin{array}{l}\text { Trinidad- } \\
\text { Tobago }\end{array}$ & Panama & Salomon Islands & Nepal & Nigeria $^{2}$ \\
\hline & & USA & Tonga & Philippines & South Africa \\
\hline & & & Vanuatu & Sri Lanka & Togo \\
\hline & & & Western Samoa $^{2}$ & Thailand & Uganda \\
\hline & & & & Viet Nam & \\
\hline
\end{tabular}

(Sources : IBPGR 1986, FAO 1996, Malaurie et al 1998a)

* in vitro maintenance for production purpose

${ }^{1}$ This country listing is not exhaustive, and take into account only sources in our possession

${ }^{2}$ Countries with in vitro collection (according to sources in our possession)

Different genebank preservation levels exist. A first group concerns non aseptic germplasm conservation with in field genebank and seed genebank, where important disadvantages and heavy constraint of quarantine measures explain the choice of in vitro germplasm conservation (Hanson, 1986; Malaurie et al., 1998a) (Table 3).

Table 3: Non aseptic germplasm conservation

\begin{tabular}{lcc}
\cline { 2 - 3 } & \multicolumn{2}{c}{ Non aseptic Genebanks } \\
\cline { 3 - 3 } Disadvantages & In field Genebanks & Seed Genebanks \\
\hline Genetic erosion & +++ & \\
Expensive & +++ & \\
Hard to manage & +++ & \\
Do not bread true & & +++ \\
Tuber shape & & +++ \\
Dormancy & & +++ \\
\hline
\end{tabular}

\section{In vitro conservation}

Three levels of in vitro genebank preservation levels could be considered: 1) short term conservation: this conservation 
under normal growth conditions is suitable for temporary storage of germplasm collections, and for international distribution, 2) medium term conservation, which could be considered as an active in vitro genebank, 3) long term conservation, considered also as a base in vitro genebank.

These in vitro genebanks have been previously introduced in vitro from tuber or seed. These introductions have to be linked to an obligatory phytosanitary control from mother plants and from in vitro material after introduction. Medium term conservation, which correspond to in vitro culture under slow growth conditions, could be obtained by several ways: 1) physiological stage of the explant, 2) addition of osmotic agents and growth moderators, 3) low storage temperature, 4) low mineral or sucrose concentrations, 5) low oxygen pressure, 6) encapsulation in alginate (Charrier et al., 1991; Withers, 1991; Engelmann, 1991; Malaurie et al., 1998a).

\section{Medium-term conservation}

At ORSTOM, we choose to maintain the in vitro yam collection in a medium with low mineral nutrient and a low sucrose concentration. We succeeded in the introduction and maintenance of 14 species of yam (Malaurie et al., 1993). Since this time, this collection is continuously enriched by new genotypes and comprises 20 species (Table 4).

For yam, this simple solution of slow growth is used routinely and from these culture conditions a direct acclimatization is possible. This mode of conservation allows an international distribution of the material and corresponds to an active genebank (Malaurie et al. 1993,1998c, Malaurie and Trouslot 1995c).

This in vitro germplasm collection of yam is maintained in test tubes, at ORSTOM (Montpellier, France), with a total of 6 test tubes by accession, with two different places of storage for the replicates; the minimal growth conditions allow to maintain most of the accessions up to 2 years. Technical constraints in the collection management lead to subculture the accessions every 6-8 months (Malaurie et al., 1998c).

Table 4 : Listing of different species of yam maintained in an in vitro collection, under slow growth culture condition*

(GeneTrop, GAP unit, ORSTOM, Montpellier, France)

\begin{tabular}{|c|c|}
\hline Species & Number of accessions \\
\hline D. abyssinica Hochst. Ex Kunth & 6 \\
\hline D. alata $\mathrm{L}$. & 91 \\
\hline D. bulbifera $\mathrm{L}$. & 8 \\
\hline $\begin{array}{l}\text { D. cayenensis Lamk. } \\
\text { D. rotundata Poir. } \\
\text { complex }\end{array}$ & $63(+17)$ \\
\hline D. burkilliana J. Miège & 11 \\
\hline D. dumetorum (Kunth) Pax. & 2 \\
\hline D. esculenta (Lour.) Burk. & 10 \\
\hline D. hirtiflora Benth. & 1 \\
\hline D. mangenotiana J. Miège & 15 \\
\hline D. minutiflora Engl. & 2 \\
\hline $\begin{array}{l}\text { D. opposita Thunb. } \\
\text { D. japonica Thunb. } \\
\text { complex }\end{array}$ & 1 \\
\hline D. praehensilis Benth. & 17 \\
\hline D. preussii $\mathrm{Pax}$ & 1 \\
\hline D. sansibarensis $\mathrm{Pax}$ & 1 \\
\hline D. schimperana Hochst. Ex Kunth & 1 \\
\hline D. smilacifolia De Wild & 2 \\
\hline D. togoensis Knuth & 8 \\
\hline D. transversa $\mathrm{Br}$. & 1 \\
\hline D. trifida $\mathrm{L}$. & $2(+1)$ \\
\hline $\begin{array}{l}\text { Interspecific Hybrids: D. cayenensis-D. rotundata } \\
\text { complex cv. 'Krengle' X D. praehensilis }\end{array}$ & 14 \\
\hline so-called 'Igname de Pilimpikou' & $(+9)$ \\
\hline
\end{tabular}

${ }^{*}(+)$ : Accessions recently introduced 
Different species maintained in the in vitro collection, such as $D$. cayenensis- $D$. rotundata complex are going to be enriched by cultivars from Burkina Faso for a sanitation program, and from Benin for a genetic program linkeds to virologic aspect. Others species supposed to be links to $D$. cayenensis- $D$. rotundata complex, such as $D$. mangenotiana, D. praehensilis, D. minutiflora, or D. abyssinica, D. praehensilis, are going to be enriched by further introduction.

Orstom virologists are interested by $D$. trifida because of its strong sensibility to virus, which provoked in Guadeloupe, French West-Indies, its quite disappearance. Serological and molecular works are developed to explain this virus sensibility.

\section{Long-term conservation}

Long term conservation correspond to cryopreservation in liquid nitrogen, at $-196{ }^{\circ} \mathrm{C}$. Plant cryobiology, which begun in 1971 by Latta works on carrot cell suspension, benefited from results on animals cell by Polge et al in 1949. Since these dates, different techniques have been set up: 1) on one hand, the so-called conventional techniques, using two steps of slow freezing, with the addition of cryo-protector (Sakai, 1984), 2) and on the other hand, new techniques, characterized by a very rapid freezing, about $1000^{\circ} \mathrm{C} / \mathrm{min}$, by direct immersion in liquid nitrogen (Table 5) (Dereuddre et al., 1990, 1991; Tannoury et al., 1991; Uragami, 1993). The aim of these techniques is to try to control water flow and ice formation, and tend to a vitrificated state, avoiding crystal formation during thawing, and to protect the cell from thermic shocks.

Table 5 : Long term conservation : cryopreservation in liquid nitrogen, $-196^{\circ} \mathrm{C}$

\begin{tabular}{|c|c|c|c|c|}
\hline \multirow[t]{2}{*}{ Steps } & \multirow{2}{*}{$\begin{array}{c}\text { Conventional } \\
\text { techniques }\end{array}$} & \multicolumn{3}{|c|}{ New techniques } \\
\hline & & Air-drying & Vitrification & $\begin{array}{c}\text { Encapsulation } \\
\text { / Dehydration }\end{array}$ \\
\hline Encapsulation & & & & + \\
\hline Sucrose pretreatment & $+/-$ & $\stackrel{+}{+}$ & & + \\
\hline Cryoprotector & + & & ++++ & \\
\hline Desiccation & & + & & + \\
\hline Slow-freezing & $\begin{array}{c}+ \\
0^{\circ} \mathrm{C} \text { to }-40^{\circ} \mathrm{C} \\
\left(0.3 \text { to } 1^{\circ} \mathrm{C} / \mathrm{min}\right)\end{array}$ & & & \\
\hline Rapid-freezing & $\begin{array}{c}+ \\
-40^{\circ} \mathrm{C} \text { to }-196^{\circ} \mathrm{C} \\
\left(200^{\circ} \mathrm{C} / \mathrm{min}\right)\end{array}$ & $\begin{array}{c}+ \\
+25^{\circ} \mathrm{C} \text { to }- \\
196^{\circ} \mathrm{C} \\
\left(720^{\circ} \mathrm{C} / \mathrm{min}\right)\end{array}$ & $\begin{array}{c}+ \\
+25^{\circ} \mathrm{C} \text { to }-196^{\circ} \mathrm{C} \\
(400 \text { to } \\
\left.1100^{\circ} \mathrm{C} / \mathrm{min}\right)\end{array}$ & $\begin{array}{c}+ \\
+25^{\circ} \mathrm{C} \text { to }-196^{\circ} \mathrm{C} \\
\left(720^{\circ} \mathrm{C} / \mathrm{min}\right)\end{array}$ \\
\hline Thawing & $500^{\circ} \mathrm{C} / \mathrm{min}$ & $120^{\circ} \mathrm{C} / \mathrm{min}$ & $120^{\circ} \mathrm{C} / \mathrm{min}$ & $120^{\circ} \mathrm{C} / \mathrm{min}$ \\
\hline
\end{tabular}

Sources : Uragami (1993), Malaurie et al. (1998a).

Most of the results about cryopreservation have been obtained from conventional techniques on suspension cells of medicinal yam, D. deltoidea being the most used ( Butenko et al., 1984; Popov and Fedorovskii, 1992; Popov and Volkova, 1994). More recent works have been done on rapid cryopreservation of callus (Chulafich et al., 1994), by direct immersion in liquid nitrogen, of two other medicinal yams (D. balcanica, D. caucasica).

Since 1996, new results have been obtained by two different research teams, using encapsulation/dehydration of shoot apices. On the one hand, Mandal et al. (1996) compared the survival capacities of apices after the osmotic 
and thermic stress of the technique of four species of yam three edible (D. alata, D. bulbifera, D. wallichii), and one medicinal (D. floribunda). Four of them have survived after immersion in liquid nitrogen, with 26 to $71 \%$, depending on the species. Meanwhile, only two of them (D. alata, D. wallichii) allowed the recovery into shoots after immersion in liquid nitrogen, with 21 and $37 \%$, respectively.

On the other hand, ORSTOM ability in different aspects of the long term conservation on tropical plants (Engelmann, 1991), and on encapsulation/dehydration technique applied on coffee, cassava, oil palm...etc, permitted to apply the process on apical shoot-tips of in vitro plantlets of yam (Malaurie and Trouslot 1996). Malaurie et al. (1998b) obtained survival rates over $50 \%$ for the two species $(D$. alata, D. bulbifera), and recovery to rooted leafy shoots after immersion in liquid nitrogen of at least $60 \%$ for $D$. bulbifera and $20 \%$ for D. alata, three months culture after thawing.

Comparatively to previous works on cryopreservation using encapsulation/dehydration technique, Malaurie et al. (1998b) have used higher sucrose concentration (0.9, 1.0 and $1.1 \mathrm{M}$ ), a wider range of dehydration duration, up to $23 \mathrm{~h}$ and a new and more accurate method for measuring of dry weight.

The new and more accurate method for measuring of dry weight used in our experiments consisted of desiccating alginate beads for $30 \mathrm{~d}$ in airtight boxes containing dry silica gel, to avoid mass loss due to caramelization of sugar when drying at a temperature higher than $100^{\circ} \mathrm{C}$. We obtained a strong linear correlation between dry mass $\left(\mathrm{DW}_{30}\right)$ and sucrose molarity for sucrose-pretreated alginate beads. During the whole experiment, we used $\mathrm{DW}_{30}$ values estimated by linear regression (Table 6).

Table 6: Dry mass and water content of sucrose-pretreated alginate beads, determined after 30d of drying with silica gel in airtight boxes at room temperature ${ }^{(1)}$.

\begin{tabular}{lll}
\hline $\begin{array}{l}\text { Sucrose } \\
\text { concentration }\end{array}$ & $\begin{array}{l}\mathrm{DW}_{30}(\% \mathrm{FW}) \text { estimated by linear } \\
\text { regression }\end{array}$ & $\begin{array}{l}\text { Water content before } \\
\text { dehydration }\left(\mathrm{g} \cdot \mathrm{g}^{-1} \mathrm{DW}\right)\end{array}$ \\
\hline $0.75 \mathrm{M}$ & 28.8 & 2.47 \\
$0.9 \mathrm{M}$ & 33.3 & 2.00 \\
$1.0 \mathrm{M}$ & 36.3 & 1.76 \\
$1.1 \mathrm{M}$ & 39.3 & 1.54 \\
\hline
\end{tabular}

(1) Source: Malaurie et al. (1998b)

(2) >From mean values over 13 to 15 replicates for each of the four sucrose concentrations $(y=6.4319+29.872 x ; N=4 ; r=0.999)$. Similar results were obtained from replicate data $(y=6.4177+29.883 x ; N=55 ; r=0.960)$. Data not shown.

For the best sucrose pretreatments depending species, figure 1 (Malaurie et al., 1998b) shows that D. bulbifera still has high survival with high sucrose concentration and after long duration dehydration (up to $23 \mathrm{~h}$ ). For the two species, the water content of encapsulated apices had to be decreased down to $0.15 \mathrm{~g} \mathrm{H}^{2} \mathrm{O} \mathrm{g}^{-1} \mathrm{DW}$ in order to obtain high survival after freezing. The percentage of water loss was of $67,62,58$ and $55 \% \mathrm{FW}( \pm 1 \%)$ for $0.75,0.9,1$ and $1.1 \mathrm{M}$ sucrose pretreatments, respectively. Our results demonstrated that, in most cases, survival increased when dehydration was extended to a defined threshold, around 0.13-0.15g. H2O g-1 DW, which was obtained after desiccation periods from 10 to $18 \mathrm{~h}$. It seemed that, with this soft dessication process, we could rub out differences in residual water-free, which certainly exist between apices from a same plot. 

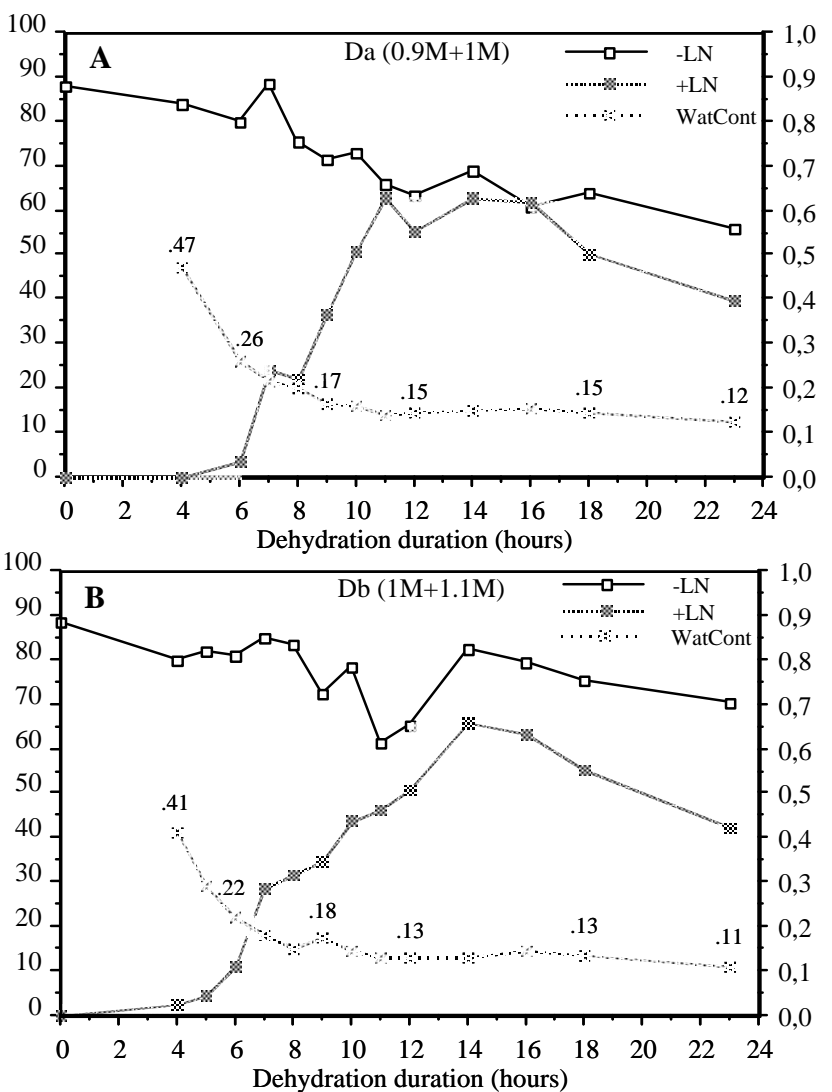

Figure 1. Effect of dehydration duration on the water content of beads and survival rate of control (-LN $\square$ ) and cryopreserved ( $+\mathrm{LN} \mathbf{-})$ encapsulated apices of $D$. alata 'Brazo Fuerte' after pretreatment with sucrose $(0.9 \mathrm{M}+1 \mathrm{M})-(\mathrm{A})$, and D. bulbifera 'Nouméa Imboro' after pretreatment with sucrose $(1 \mathrm{M}+1.1 \mathrm{M})$ - pretreated ones $(\mathrm{B})$. Each point corresponds to a mean over 2 sucrose concentrations and all the 6 or 8 pretreatment durations used depending on the clone (Malaurie et al., 1998b).

\section{Indexation and Disease-free germplasm production}

\section{Indexation}

In vitro germplasm conservation presents different advantages such as: 1) to be free from genetic erosion, 2) to have the possibility for the establishment of core collection with long term genebanks, 3) to be free from fungis and bacteria, 4) to be not expensive, when in vitro facilities are already present, 5) easy and convenient for international distribution. But International exchanges need more for safe international exchange. We need to know the plant material on genetic level, and over all on the phytosanitary level. On the phytosanitary level, various viruses have been described on edible and medicinal yams on their production area. Different works, depending virus and virus group, are reported (Table 7). Indexing techniques allow to highlight a certain number of viruses on yam: Poty, potex, badna and cucumo-viruses, where yam mosaic virus (YMV) provokes the most important loss.

Table 7: Viruses of yam: group and type viruses, yam species affected and reference works

\begin{tabular}{|c|c|c|c|c|c|}
\hline Virus Group & Virus & $\begin{array}{c}\text { Yam species } \\
\text { affected }\end{array}$ & $\begin{array}{c}\text { Geographic } \\
\text { spreading }\end{array}$ & $\begin{array}{c}\text { Disease } \\
\text { importance }\end{array}$ & Authors \\
\hline Cucumovirus & $\mathrm{CMV}$ & $\begin{array}{l}\text { D. alata, } \\
\text { D. } \\
\text { cayenensis- } \\
\text { D. Rotundata } \\
\text { complex, D. } \\
\text { Trifida }\end{array}$ & $\begin{array}{c}\text { Caribbean } \\
\text { and West- } \\
\text { Africa }\end{array}$ & - & $\begin{array}{c}\text { Migliori, 1977; Fauquet and } \\
\text { Thouvenel, } 1987\end{array}$ \\
\hline
\end{tabular}

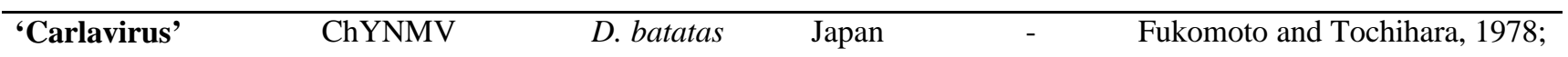




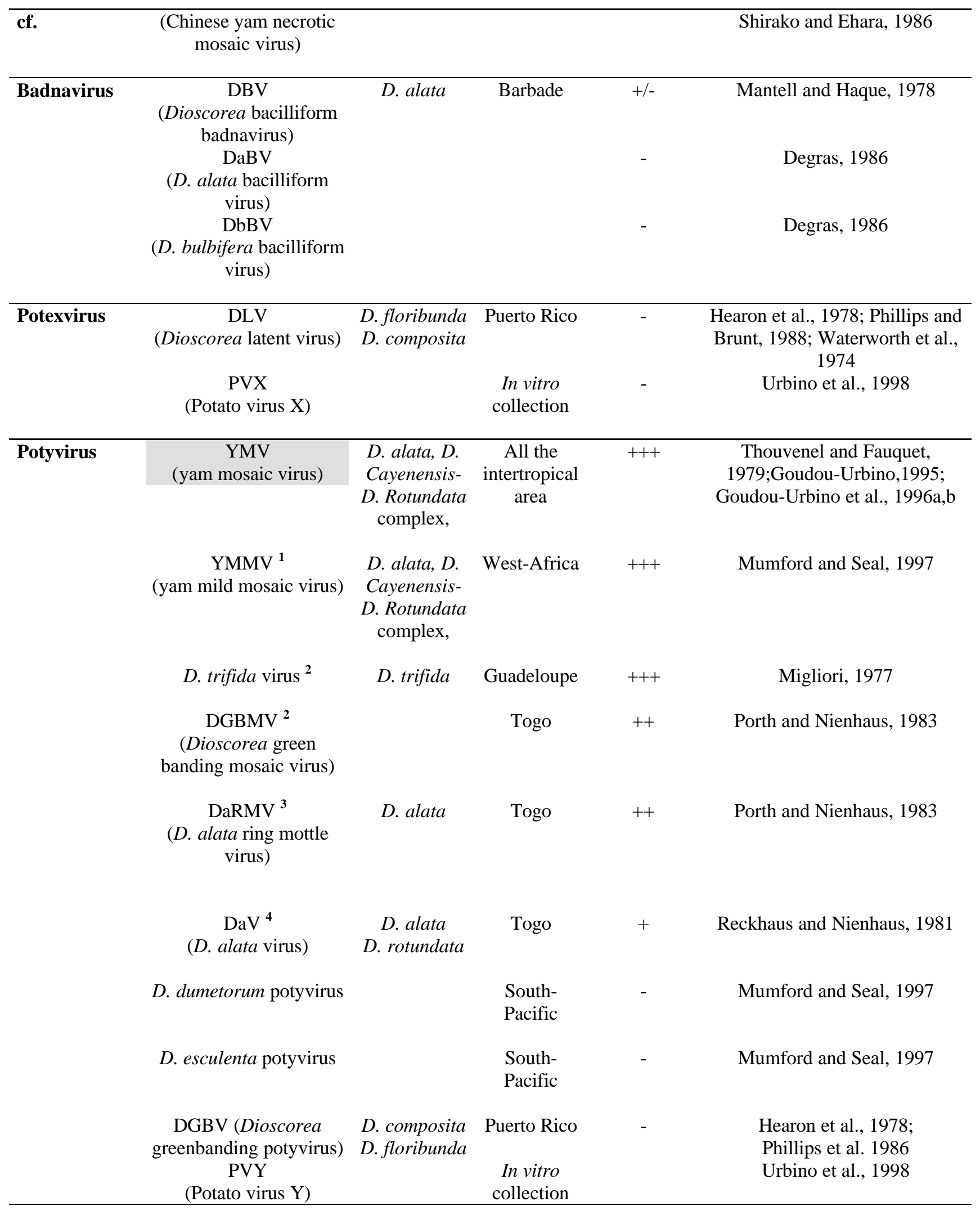

${ }^{1}$ YMMV: is it a new potyvirus or a strain of the YMV?

${ }^{2}$ D. trifida virus and DGBMV have been shown as YMV strains (Porth et al.,1987)

${ }^{3}$ DaRMV should be a 'yam strain' of the beet mosaic potyvirus transmissible on N. benthamiana (Porth et al.,1987)

${ }^{4} \mathrm{DaV}$ is serologically links toYMV but differ by is non-transmissibility (Porth et al.,1987) 
During the establishment of the yam in vitro germplasm collection, in the biotechnology laboratory of ORSTOM (Malaurie et al., 1993), afterwards IIRSDA - Adiopodoumé research station, near Abidjan, Ivory Coast - clones were systematically indexed by ELISA directed to YMV, when introduced in vitro (Malaurie and Thouvenel, 1988; Malaurie et al., 1988a,b; Charrier and Hamon, 1991).

Later on, one indexation was carried out by a virologist team on the duplicate of the yam in vitro germplasm collection enriched by introduction of new genotypes. 92 samples, belonging to several yam species, were used for the indexation : D. alata, D. bulbifera, D. cayenensisrotundata complex, D. dumetorum, D. esculenta, D. mangenotiana, D. praehensilis, D. shimperiana, $D$. togoensis, D. trifida. These samples were originating from various geographic areas: Africa, Caribbean, South America and Asia. Four viruses were fetched by ELISA technique: PVX (potato virus X, potexvirus) PVY (potato virus Y, potyvirus), CMV (cucumber mosaic cucumovirus), and YMV (Urbino et al. 1998). Results are presented in Table 8.

Table 8: Indexation of the ORSTOM in vitro yam collection

\begin{tabular}{lcccc}
\hline ELISA results & PVX & PVY & CMV & YMV \\
\hline \% Positives & 5,5 & 6,3 & 2,1 & 7,7 \\
\% Negatives & 94,5 & 93,7 & 97,9 & 92,3 \\
\hline
\end{tabular}

Source: Urbino et al. (1998)

This study allowed to show that detection of viruses serologically linked to PVX and to PVY, in different yam species, was possible, even with the same frequencies than with YMV. Further works have to be done for a precise caracterization of these virus isolates, and check their respective importance in natural environement. Experiments using more sophisticated techniques for virus diagnostic (IC/rt/PCR) are developed (Bousalem, 1995). Yam on molecular caracterization and molecular diversity on potyvirus of the yam mosaic virus (YMV) have been developed on the ILTAB/ORSTOM-TSRI laboratories (Aleman, 1996; Aleman et al 1996a,b) and from the LPRC laboratory (Bousalem, 1995; Urbino et al., 1998).

\section{Virus eradication techniques}

The use of in vitro techniques allows to be free from fungis, bacteria, and other pests. Only viruses could be present on the plant and have to be eradicated. Different techniques exist and are already applied on yam. There are meristem culture, thermotherapy and/ or chemotherapy $\left(36^{\circ} \mathrm{C}\right.$ during 1 to 2 weeks on in vivo or in vitro plants, use of chemicals such as vidarabine, ribavirin and 2-thiouracil). They could be used alone or associated (Table 9).

Table 9 : Yam disease eradication techniques

\begin{tabular}{|c|c|c|c|c|c|}
\hline & Eradication techniques & Species & Authors & $\begin{array}{c}\text { Type of } \\
\text { use* }\end{array}$ & $\begin{array}{c}\text { Virus } \\
\text { eradicati } \\
\text { on }\end{array}$ \\
\hline (A) & meristem culture & $\begin{array}{l}\text { D. cayenensis-rotundata, } \\
\text { D. japonica, D. opposita, } \\
\text { D. praehensilis, } \\
\text { D. rotundata, D. trifida, } \\
\text { Dioscorea } \text { spp. }\end{array}$ & $\begin{array}{l}\text { Cortes Monllor et } \\
\text { al., 1982; } \\
\text { Kobayashi, 1991; } \\
\text { Malaurie et al., } \\
\text { 1988a,b, 1992, } \\
\text { 1995a,b; Malaurie } \\
\text { and Thouvenel, } \\
\text { 1988; Matsubaru } \\
\text { and Ishira, 1988; } \\
\text { Mikami, 1984; } \\
\text { Saleil et al., 1990; }\end{array}$ & $\mathrm{E}$ & $+/-$ \\
\hline (B) & $\begin{array}{c}\text { Thermotherapy in vivo }+ \\
\text { meristems culture }\end{array}$ & D. alata & $\begin{array}{c}\text { Mantell et al., } \\
1980\end{array}$ & $\mathrm{E}$ & + \\
\hline (C) & $\begin{array}{l}\text { Nodal microcutting or } \\
\text { apices + Thermotherapy }\end{array}$ & D. alata, D. Trifida & $\begin{array}{l}\text { Balagne, 1985; } \\
\text { Salazar and } \\
\text { Fernandez } 1988\end{array}$ & $\mathrm{E}, \mathrm{R}(+/-)$ & + \\
\hline (D) & Nodal microcutting + & D. alata & Mantell, 1993 & $\mathrm{E}, \mathrm{R}(+/-)$ & + \\
\hline
\end{tabular}




\begin{tabular}{|c|c|c|c|c|c|}
\hline (E) & $\begin{array}{l}\text { Chemotherapy } \\
\text { Nodal microcutting + } \\
\text { Thermotherapy \&/or } \\
\text { Chemotherapy }\end{array}$ & D. praehensilis & $\begin{array}{c}\text { Malaurie, } \\
\text { unpublished results }\end{array}$ & $\mathrm{E}$ & $+1-$ \\
\hline (F) & $\begin{array}{c}\text { Meristem culture + } \\
\text { Thermotherapy \&/or } \\
\text { Chemotherapy }\end{array}$ & $\begin{array}{l}\text { D. cayenensis-rotundata, } \\
\text { D. praehensilis }\end{array}$ & $\begin{array}{c}\text { Malaurie, } \\
\text { unpublished results }\end{array}$ & $\mathrm{E}$ & $+/-$ \\
\hline
\end{tabular}

* E: experimental use; R: routine use

Success in meristem culture depends on the size and location of the explant excised, and on the growth regulator ratio. 'Meristem culture', on Table 9, concerns works using meristem-tips (0.2-0.5 mm long) as well as shoot-tips (0.6$2.5 \mathrm{~mm}$ long). Experiments on viability and in vitro morphological development of meristem-tips of two sizes, 'small' (0.3-0.5 mm) and 'large' (0.6-0.8 mm), have shown that it was better to use large meristem size to increase the shoot elongation percentage. The use of axillary or apical meristems did not induce difference and should allow an important yield in micropropagating such material from excised meristem-tips. Eleven months after meristem excision, production of plantlets was observed with a rate of $82 \%$ and $39 \%$ from the survivors, for a clone of $D$.
cayenensis-D. rotundata complex and D. praehensilis genotype, respectively (Malaurie et al., 1995a,b).

Meristem cultures have been done on 8 clones of 5 Dioscorea species belonging to the in vitro germplasm collection. Morphological development has been observed and data were recorded 60 days after meristem inoculation. In our case, the production of rooted leafy shoots, 60 days after meristem inoculation, occurred in five clones out of eight, with percentage shoot leaf production of 5 to $26 \%$, depending on the clone. Six months later, the excised meristems of all clones developed into rooted leafy shoots, where $D$. bulbifera, and $D$. dumetorum was not, to our knowledge, mentioned in the literature (Table 10).

Table 10: Genotypic effect on morphogenetic orientation 2 months after meristem excision of Dioscorea spp *

\begin{tabular}{|c|c|c|c|c|}
\hline & $\begin{array}{c}\text { Total meristems } \\
\text { observed }\end{array}$ & $\begin{array}{c}\text { Necrosis } \\
\% \\
\end{array}$ & $\begin{array}{c}\text { Organogenesis }^{2)} \\
\% \\
\end{array}$ & $\begin{array}{c}\text { Regeneration }^{3)} \\
\%\end{array}$ \\
\hline D. alata & 67 & 27 & 55 & 18 \\
\hline D. bulbifera & 252 & 46 & 37 & 18 \\
\hline D. bulbifera & 146 & 52 & 48 & 0 \\
\hline $\begin{array}{l}\text { D. cayenensis-D. } \\
\text { rotundata complex }\end{array}$ & 23 & 65 & 35 & 0 \\
\hline $\begin{array}{l}\text { D. cayenensis-D. } \\
\text { rotundata complex }\end{array}$ & 81 & 24 & 51 & 26 \\
\hline $\begin{array}{l}\text { D. cayenensis-D. } \\
\text { rotundata complex }\end{array}$ & 81 & 26 & 54 & 20 \\
\hline D. dumetorum & 24 & 83 & 17 & 0 \\
\hline D. praehensilis & 117 & 41 & 54 & 5 \\
\hline
\end{tabular}

1) Necrosis. 2) Organogenesis: callusing, rooting, swelling were added together, ${ }^{3)}$ Regeneration: meristem development into rooted leafy shoots and axillary bud development or bud neoformation.

* (Malaurie, unpublished results)

Works about production of virus-free in vitro plants of yam through yam meristem culture alone are very rare. Saleil et al. (1990) on D. trifida obtained YMV-free plants, after ELISA indexation with a $27 \%$ rate through the total indexed plants. Nevertheless, other unpublished results on 2 genotypes YMV-infected of 2 species (D. cayenensis- D. rotundata complex, $D$. praehensilis) showed that meristem culture allowed the production of virus-free plants with $76 \%$ and $17 \%$ plants indexed, respectively (Malaurie, unpublished results).
Production of virus-free in vitro plants of yam has been attempted through thermotherapy, chemotherapy associated or not, from in vivo mother plants, nodal cuttings or apices (Balagne, 1985; Mantell, 1993; Mantell et al., 1980; Salazar and Fernandez, 1988). None of them described clearly the percentage of virus-free plants obtained through these techniques. Meanwhile, the production of plantlets free from virus is described by Mantell (1993) on D. alata cv. Kinabayo, after the action of antiviral agents (vidarabin, ribavirin) on nodal microcuttings infected by a potyvirus. The production of virus-free plants have been obtained 210 
days after in vitro inoculation, after 3 subcultures of 60,120 and 30 days on a liquid/solid biphasic cuture system with $10^{-5} \mathrm{M}$ of antiviral agent.

Other available techniques could be electrotherapy used on potato, with 60 to $100 \%$ success as compared to $25-40 \%$ with thermotherapy (Lozoya-Saldaña et al., 1996; Bernal et al., 1998), or apex micrografting, used on Lemon tree or vine, routinely.

If different works have already been done on yam sanitation, only a few of them conducted to an eradication of virus with more or less importance.

\section{Safe international exchange}

Exchange and distribution of plant material could be done by two ways: 1) with non aseptic plant material (tubers, aerial tubers, seeds, nodal cuttings from the vine), 2) with plant material in aseptic conditions (micro-nodal cuttings, microtubers, aerial microtubers, apices, zygotic or somatic embryos, callus and cells suspension).

Exchange in non-aseptic conditions was used in the past, but required severe quarantine measures. Since 1989, with the FAO/IBPGR technical guidelines for the safe movement of yam germplasm, recommendation has been given to use in vitro conditions for exchange and distribution. For that, safe movement of yam germplasm could be done easily by three ways: 1) micro-nodal cuttings, 2) micro-tubers, 3) or encapsulated apices.

Safe movement of yam germplasm by micro-nodal cuttings is the most common way and has been frequently used (Malaurie et al., 1998a). In Table 11, the use of laboratories with in vitro and quarantine facilities allowed the indexation, in vitro introduction and micropropagation for a safe diffusion of various genotypes from different geographical origin.

Table 11: Enrichment of the genetic diversity of a country by transfer and introduction of in vitro yam genotypes from different geographic origins*

\begin{tabular}{cccc}
\hline Species & Number of accession & Sending countries & Receiving countries \\
\hline D. alata & 6 & Ivory Coast & New Caledonia \\
D. alata & 5 & West Indies & New Caledonia \\
D. alata & 1 & Brazil & New Caledonia \\
D. alata & 5 & West Indies & Ivory Coast \\
D. alata & 3 & New Caledonia & Ivory Coast \\
D. alata & 3 & Brazil & Ivory Coast \\
$\begin{array}{l}\text { D. bulbifera } \\
\text { D. } \text { cayenensis- } D \text {. }\end{array}$ & 1 & New Caledonia & Ivory Coast \\
rotundata complex & 4 & Ivory Coast & New Caledonia \\
D. cayenensis- $D$. & 1 & & Brazil \\
rotundata complex & & & Ivory Coast \\
\hline
\end{tabular}

* All plant material from the sending countries were, at first, tubers sent to laboratories with quarantine and in vitro culture facilities (1988-89: Orstom \& Iirsda, Adiopodoumé, Côte d'Ivoire; 1992-95: Orstom, LRGAPT, Montpellier) for their in vitro introduction and micropropagation, preliminary to all safe international exchange.

Tuber potentiality shown by a great number of in vitro yams (aerial and basal micro-tubers) could be also used for a safe transfer of yam germplasm. They could increase the percentage of success during their acclimatation in field (John et al.,1993; Malaurie et al., 1993; Mantell, 1993; Ng, 1988; Ng and Mantell, 1997). These tubers developed in vitro are dormant at maturity and they still keep their dormancy from 2 to 5 months, as tubers developed in vivo. Recently a new method, experimented over three yam species (D. alata, D. opposita, D. rotundata), has been proposed by Hasan and Takagi (1995). They use encapsulation technique, with the embeddment of nodal cuttings in alginate beads, for a concept of a material transfer. This process allow to maintain in the dark for at least 2 weeks. These 2 weeks in the dark allow to envisage a safe and easy international exchange of genetic resources.

\section{Concluding Remarks}

This paper tries to describe different studies done and to be done on yam in vitro germplasm conservation and its safe international exchange. Yam in vitro culture contributes to the safeguard of the biodiversity of the genus Dioscorea. An application of the results obtained on cryopreservation to more species should allow a transfer of technology. The use of new techniques, in a one hand, for pathogen eradication (electrotherapy, micrografting), in addition to the existent ones, and in the other hand, for the obtention of plants resistant to somes viruses (transformation), should guarantee to yam a state of virus-free plant and allow 
international exchanges, and in long term, distribution to the farmer of cultivar free from virus.

To conclude we can say that we are already able to manage routinely yam in vitro genebanks in slow growth culture, to index for more viruses, and to produce some virus-free in vitro plantlets.

For an efficient distribution - transfer - utilisation of yam germplasm, we should develop: 1) virus-free germplasm, 2) restricted size collection, with large diversity, so-called core-collections. For that, in vitro conservation under slow growth condition and cryopreservation, have to be applied routinely to more genotypes; virus-indexing has to be done with more precise techniques (rt/PCR); therapy has to be done with several combined techniques to become genotype independant.

But, we should not forget, as previously said by Hanson (1986), that, for a better security of germplasm conservation, different methods of conservation have to be combined (in situ - Field Genebanks - , ex situ - Seed Genebanks, in vitro Genebanks).

\section{References}

Aleman, M.E. (1996). Caractérisation moléculaire, diversité génétique et contrôle du virus de la mosaïque de l'igname (YMV). These, Doctorat en sciences agronomiques. ENSAM, Montpellier, France, 138p.

Aleman, M.E., Goudou-Urbino, C., Dubern, J. and Fauquet, C. $\left(1996^{\mathrm{a}}\right)$. Analysis of sequence variations in the P1, HC, P3, NIb and CP regions of Yam Mosaic Potyvirus isolates: implications for potyvirus intra-species molecular diversity. Journal of General Virology 78: 1253-1264.

Aleman, M.E., Marcos, J.F., Brugidou, C., Fux, C.I., Goudou-Urbino, C. and Dubern, J. (1996b). Genomic Organization, Molecular Diversity and Control of Yam (Dioscorea) Mosaic Virus. ILTAB Review 1991-1996, p. 81-82.

Ayensu, E.S. and Coursey, D.G. (1972). Guinea yams. The botany, ethnobotany, use and possible future of yams in West Africa. Economic Botany 26:301-318.

Balagne, M. (1985). Le microbouturage in vitro de l'igname cousse couche Dioscorea trifida en vue de son application pour la guérison des variétés atteintes de viroses. Thèse de 3ème cycle, USTL, Montpellier, 144 p.

Bernal, F.J.M., Hernández, R.P., Noa, J.C., Pichardo, T.P., Igarza, Y.C., Sarria, Z. and Agromonte, D.P. (1998). Técnicas de saneamiento para la obtención de papa (Solanum tuberosum L.) var. Desirée libre del virus del enrollamiento de la hoja. REDBIO'98-3 ${ }^{\text {rd }}$ Latin-American Meeting on Plant Biotechnology, June 1-5, La Habana, Cuba, p. 137.
Bousalem, M. (1995). Mise au point d'outils immunologiques et moléculaires pour la détection et la caractérisation des potyvirus infectant l'ignameCaractérisation moléculaire préliminaire de l'isolat BFC 56 du Yam Mosaic Virus. Laboratoire de Phytovirologie des Régions Chaudes (LPRC), Montpellier, Cirad-Orstom, 23p. (document interne).

Burkill, I.H. (1960). The organography and the evolution of Dioscoreaceae, the family of the yams. J. Linn. Soc. (Bot.) 56:319-412.

Butenko, R.G., Popov, A.S., Volkova, L.A., Chernyak, N.D. and Nosov, A.M. (1984). Recovery of cell cultures and their biosynthetic capacity after storage of Dioscorea deltö̈dea and Panax ginseng cells in liquid nitrogen. Plant Science Letters 33: 285-292.

Charrier, A., Dereuddre, J., Engelmann, F. (1991). The implications of biotechnology in germplasm conservation and utilization. Crop Genetic Resources of Africa. Vol II. N.Q. Ng, P. Perrino, F. Attere, H. Zedan ed., Ibadan, Nigeria, IITA/IBPGR/UNEP/CNR, In: Proceedings of an International Conference on Crop Genetic Resources of Africa. pp. 279-286.

Charrier, A. and Hamon, S. (1991). Germplasm collection, conservation and utilization activities of the Office de la Recherche Scientifique et Technique d'Outre-Mer (ORSTOM). Crop Genetic Resources of Africa. Vol II. N.Q. Ng, P. Perrino, F. Attere, H. Zedan ed., Ibadan, Nigeria, IITA/IBPGR/UNEP/CNR. In: Proceedings of an International Conference on Crop Genetic Resources of Africa. pp. 41-52.

Chulafich, L., Grubishich, D., Vuiichich, R., Volkova, L.A. and Popov, A.S. (1994). Somatic embryo production in vitro in Dioscorea caucasica Lipsky and Dioscorea balcanica Kosanin and cryopreservation of their organogenic callus tissue. Russian Journal of Plant Physiology 41:821-826.

Cortes Monllor, A., Liu, L.J. and Arroyo, E. (1982). An improved medium for tissue culture of yam Dioscorea sp. in vitro in Puerto Rico. Phytopathology 72:171.

Coursey, D.G. (1967). Yams, London, Longmans, 230 p.

Degras, L. (1986). L'igname, Techniques Agricoles et Productions Tropicales, Ed. G.P. Maisonneuve et Larose \& Agence de Coopération Culturelle et Technique, 409 p.

Dereuddre, J., Scottez, C., Arnaud, Y. and Duron, M. (1990). Résistance d'apex caulinaires de vitroplants de poirier (Pyrus communis L. cv Beurré Hardy), enrobés dans l'alginate, à une deshydratation puis à une congélation dans l'azote liquide: effet d'un endurcissement préalable au froid. C. R. Acad. Sc. Paris, Série III, 310:317-323. 
Dereuddre, J., Blandin, S. and Hassen, N. (1991). Resistance of alginate-coated somatic embryos of carrot (Daucus carota L.) to dessication and freezing in liquid nitrogen: 1- Effects of preculture. Cryo-Letters 12:1125134.

Engelmann, F. (1991). In vitro conservation of tropical plant germplasm - a review. Euphytica 57:227-243.

Fauquet, C. and Thouvenel, J.C. (1987). Cucumber mosaic on sweet potato and yam. In: Plant Viral Diseases in the Ivory Coast, Documentations Techniques $n^{\circ}$. 46, Editions de l'Orstom, Paris, p. 29.

FAO/IBPGR (1989). Technical guidelines for the safe movement of yam germplasm. A.A. Brunt, G.V.H. Jackson, E.A. Frison, ed., Rome, pp. 1-20.

FAO (1996). The State of the World's Plant Genetic Resources for Food and Agriculture. Background Documenation prepared for the International Technical Conference on Plant Genetic Resources, Leipzig, Germany, 17-23 June, 1996. FAO : Rome, 336 p.

Fukomoto, F. and Tochihara, H. (1978). Chinese yam necrotic virus. Annals of the . Phytopathological Society of Japan 44:1-5.

Goudou-Urbino, C. (1995). La mosaïque de l'igname: aspects épidémiologiques au Burkina-Faso et variabilité du virus. Thèse de l'Université Montpellier II, $147 \mathrm{p}$.

Goudou-Urbino, C., Givord, L., Quiot, J.B., Boeglin, M., Konate, G. and Dubern, J. (1996a). Differentiation of yam virus using symptomatoloy, western blot assay, and monoclonal antibodies. Journal of Phytopathology $144: 235-240$.

Goudou-Urbino, C., Konate, G., Quiot, J.B. and Dubern, J. (1996b). Etiology and ecology of yam mosaic disease in Burkina Faso. Tropical Sciences, 36:34-40.

Hanson, J. (1986). Methods of storing tropical root crop germplasm with special reference to yam. FAO/IBPGR Plant Genetic Ressources Newsletter 64:24-32.

Hasan, S.M.Z. and Takagi, H. (1995). Alginate-coated nodal segments of yam (Dioscorea spp.) for germplasm exchange and distribution. Plant Genetic Resources Newsletter 103:32-35.

Hearon, S.S., Corbett, M.K., Lawson, R.H., Gillespie, A.G. and Waterworth H.E. (1978). Two flexuous-rod viruses in Dioscorea floribunda: symptoms, identification and ultrastructure. Phytopathology 68:1137-1146.

IBPGR (1986). 2. Root and Tuber Crops (2nd Ed.), In Directory of Germplasm Collections. J. Toll, T. Lawrence,
D.H. Van Sloten Ed. International Board for Plant Genetic Resources, Rome, pp. 130-155.

John, J.L., Courtney, W.H. and Decoteau, D.R. (1993). The influence of plant growth regulators and light on microtuber induction and formation in Dioscorea alata L. cultures Plant Cell, Tissue and Organ Culture 34:245-252.

Knuth, R. (1924). Dioscoreaceae. A. Engler. Das Pflanzenreich, IV-43, 87. Heft, 1-387.

Kobayashi, N. (1991). Production of virus-free plants and its mass propagation by tissue culture in Chinese yam, Dioscorea opposita Thunb. Bulletin of the Saitama Horticultural Experiment Station. $\mathrm{N}^{\circ} 18,81-99$.

Latta, R. (1971). Preservation of suspension culture of plant cells by freezing. Canadian Journal of Botany 40: 2531254 .

Lozoya-Saldana, H, Abello, F.J. and Garcia G. de la R. (1996). Electrotherapy and shoot tip culture eliminate potato virus $\mathrm{X}$ in potatoes. American Potato Journal 73:149-154.

Malaurie, B., Tardieu, F. and Thouvenel, J.C. (1988a). Rapid production of disease-free germplasm of Dioscorea spp. (Monocotyledonous). In: Proceedings of 8th International Biotechnology Symposium, Paris, 17-22 July 1988, p. 248.

Malaurie, B., Tardieu, F. and Thouvenel, J.C. (1988b). Improving Yam (Dioscorea spp.), using Biotechnology. 1) Rapid production of disease free germplasm. In: Proceedings of the International Society for Root Crops Symposium. Bangkok, 30/10-5/11/1988, p. 51.

Malaurie, B. and Thouvenel, J.C. (1988). Production de plants d'Igname, dépourvus de viroses, par culture de méristèmes. $2^{\circ}$ Salon International de la Coopération et de l'Aide au Développement (SICAD). 7-11/12/1988, Montpellier, Poster Session, 3 p.

Malaurie, B., Pungu, O., Dubern, J. and Thouvenel, J.C. (1992). Determination of the best conditions for the regeneration of microplants and the elimination of YMV from excised meristems of yam nodal cuttings (Dioscorea spp.). Association of Applied Biologists. Plant Virology in the Tropics. University of York. 9-10 April 1992.

Malaurie, B., Pungu, O., Dumont, R. and Trouslot, M.F. (1993). The creation of an in vitro germplasm collection of yam (Dioscorea spp.) for genetic resources preservation. Euphytica 65: 113-122. Corrigendum 66: 243.

Malaurie, B., Pungu, O. and Trouslot, M.F. (1995a). Effect of growth regulators concentrations on morphological development of meristem-tips in Dioscorea cayenensis-D. 
rotundata complex and D. praehensilis. Plant Cell, Tissue and Organ Culture 41:229-235.

Malaurie, B.,Thouvenel, J.-C. and Pungu, O. (1995)b. Influence of meristem-tip size and location on morphological development in Dioscorea cayenensis-D. rotundata complex 'Grosse Caille' and one genotype of $D$. praehensilis. Plant Cell, Tissue and Organ Culture 42: 215218.

Malaurie, B. and Trouslot, M.F. (1995c). Les Ignames. In Biotechnologies végétales BV9D, CNED-AUPELF-UREF ed., chapitre 10:49-77.

Malaurie, B. and Trouslot, M.F. (1996). Cryopreservation of in vitro yam (Dioscorea sp.) apices by the encapsulationdehydration technique. Eucarpia, Meeting on Tropical Plants, Marsh 11-15 1996, France, Abstract, p 252.

Malaurie, B., Trouslot, M.F. and Berthaud, J. (1998a). Conservation et échange de germoplasme chez les ignames (Dioscorea spp.).'L'igname: Plante Séculaire et Culture d'Avenir'. eds. J. Berthaud, N. Bricas, J.-L. Marchand, Montpellier 3-6 Juin 1997, In : Acte du séminaire international Cirad-Inra-Orstom-Coraf, France. 135-161.

Malaurie, B., Trouslot, M.F., Engelmann, F. and Chabrillange, N. (1998b). Effect of pretreatment conditions on the cryopreservation of in vitro-cultured yam (Dioscorea alata 'Brazo Fuerte' and D. bulbifera 'Nouméa Imboro') shoot apices by encapsulation-dehydration. Cryo-Letters 19:15-26.

Malaurie, B., Trouslot, M.F., Berthaud, J., Chabrillange, N., Récalt, C. and Dussert, S. (1998c). The use of slow growth condition culture and cryopreservation in liquid nitrogen for medium and long term conservation and utilisation of in vitro yam (Dioscorea spp.) germplasm. In: Proceedings of the Workshop on Conservation \& Utilisation of Cassava, Sweetpotato and Yam Germplasm in Sub-Saharan Africa. Nairobi, November 11 to 13, 1997, (in press).

Mandal, B.B., Chandel, K.P.S. and Dwivedi, S. (1996). Cryopreservation of yam (Dioscorea spp.) shoot apices by encapsulation-dehydration. Cryo-Letters 17:165-174.

Mantell, S.H. and Haque, S.Q. (1978). Incidence of internal brown spot disease in White lisbon (D. alata) during storage. Experimental Agriculture 14:167-172.

Mantell, S. H., Haque, S. Q. and Whitehall, A. P. (1980). Apical meristem tip culture for eradication of flexous rod viruses in yams (Dioscorea alata). Tropical Pest Management $26: 170-179$.

Mantell, S.H. (1993). Integrated use of micropropagation and conventional propagation techniques for production of certified seed tubers of tropical yams (Dioscorea spp.).
Adapted propagation techniques for commercial crops of the tropics, IFS, Vietnam, 02/1993. In: Proceedings of the Southeast Asian Regional Workshop on Propagation Techniques for Commercial Crops of the Tropics 66-93.

Martin, F.W. and Degras, L. (1978). Tropical yams and their potential. Part 6. Minor cultivated Dioscorea species. USDA agriculture handbook $\mathrm{n}^{\circ} 538.23 \mathrm{p}$.

Martin, F.W. and Rhodes, A.M. (1978). The relationship of Dioscorea cayenensis and D. rotundata. Tropical Agriculture, Trin., 55:193-206.

Matsubara, S. and Ishihara, M. (1988). Production and vegetative propagation of virus-free plants of Dioscorea species. Scientific Reports of the Faculty of Agriculture, Okayama University, $\mathrm{N}^{\circ} 72,19-26$.

Miège, J. (1982). Etude chimiotaxonomique de dix cultivars de Côte d'Ivoire relevant du complexe Dioscorea cayenensis-D. rotundata. Yams-Ignames, J. Miège, S.N. Lyonga, Ed., Claredon Press Oxford, pp. 197-231.

Migliori, A. (1977). Maladies à virus de l'igname Dioscorea spp. Nouvelles agronomiques Antilles Guyane 3:428-435.

Mikami, T. (1984). Virus-free plant propagation through meristem-tip culture of Japanese yam and garlic. Research Journal of Food and Agriculture 7:17-20.

Mumford, R.A. and Seal, S.E. (1997). Detection and characterization of yam potyviruses. In: Yam viruses, Annual Collaborators Meeting, IITA - JIC - NRI, Gatsbyfunded Biotechnology Projects, 7-9 February 1997, IITA, Ibadan, Nigeria, Extended Abstracts, pp. 14-15.

$\mathrm{Ng}$, S.Y.C. (1988). In vitro tuberization in white yam (Dioscorea rotundata Poir.). Plant Cell, Tissue and Organ Culture 14:121-128.

Ng, S.Y.C. and Mantell, S.H. (1997). Technologies for Germplasm Conservation and Distribution of pathogen-free Dioscorea yams to National Root Crop Research Programmes. ODA Project R4886 (H) Final Report. Wye College University of London, UK, 12p.

Phillips, S. and Brunt, A.A. (1988). Dioscorea latent virus. AAB Descriptions of Plant Viruses, $N^{\circ}$. 335. Association of Applied Biologists, Wellesbourne.

Phillips, S., Pigott, J. d'A. and Brunt, A.A. (1986). Further evidence that Dioscorea latent virus is a potexvirus. Annals of Applied Biology 109:137-145.

Polge, C.A., Smith, A.V. and Parkes, A.S. (1949). Revival of spermatozoa after vitrification and dehydratation at low temperature. Nature 164: 666. 
Popov, A.S. and Volkova, L.A. (1994). Cryopreservation and some characteristics of Dioscorea deltö̈dea cell cultures in the vitamin-free medium. Russian Journal of Plant Physiology 41:815-820.

Popov, A.S. and Fedorovskii, D.N. (1992). Injuries to the plasmalemma of Dioscorea cells cultured in vitro incurred in the process of their cryopreservation. Soviet Plant Physiology 39:211-216.

Porth, A., Lesemann, D.-E. and Vetten, H.J. (1987). Characterization of potyvirus isolates from West Africa yams (Dioscorea spp.). Journal of Phytopathology 120:166-183.

Porth, A. and Nienhaus, F. (1983). Dioscorea alata ring mottle virus, a new potyvirus in yam in Togo. Zeitschrift fur Pflanzenkrankheiten und Pflanzenschutz 90:352-362.

Reckhaus, P. and Nienhaus, F. (1981). Etiology of a virus disease of white yam $D$. rotundata in Togo. Journal of plant disease and protection 88:492-509.

Sakai, A. (1984). Cryopreservation of apical meristems. In Horticultural Reviews, J. JANICK Ed., Purdue University, pp. 357-372.

Salazar, S.S and Fernandez, R.Z.Z. (1988). Thermotherapy, shoot tip culture, axillary bud proliferation and plant regeneration in yam (Dioscorea trifida L.). In VIIth Symposium of the International Society for Tropical Root Crops, Gosier (Guadeloupe), 1-6 July 1985, INRA Ed., Paris, p. 439-445.

Saleil, V., Degras, L. and Jonard, R. (1990). Obtention de plantes indemnes du virus de la mosaïque de l'igname (YMV) par culture in vitro des apex chez l'igname americaine Dioscorea trifida L. Agronomie 10:605-615.

Shirako, Y. and Ehara, Y. (1986). Rapid diagnosis of chinese yam necrotic mosaic virus infection by electro-blot immunoassay. Annals of the Phytopathological Society of Japan 52: 453-459.

Tanaka, S. (1977). Chinese yam Dioscorea opposita Thunb. in Japan. Tropical Root and Tuber Crops Newsletter $n^{\circ} 10$, pp. 4-5.

Tannoury, M., Ralambossa, J., Kaminske, M. and Dereuddre, J. (1991). Cryoconservation par vitrification d'apex enrobés d'oeillets (Dianthus caryophyllus L.) cultivés in vitro. C. R. Acad. Sc. Paris, Série III, 313:633638.

Thouvenel, J.-C. and Fauquet, C. (1979). Yam mosaïc, a new potyvirus infecting Dioscorea cayenensis in the Ivory Coast. Annals of Applied Biology 93:279-283.
Uragami, A. (1993). Cryopreservation of cultured cells and organs of vegetables. In Reprint from JICA GRP REF $\mathrm{N}^{\circ} 6$, 111-135.

Urbino, C., Bousalem, M., Pinel, A., Fargette, D. and Dubern, J. (1998). Les Virus de l'igname: aspects épidémiologiques et variabilité.'L'igname: Plante Séculaire et Culture d'Avenir'. eds. J. Berthaud, N. Bricas, J.-L. Marchand, Montpellier 3-6 Juin 1997, In : Acte du séminaire international Cirad-Inra-Orstom-Coraf, France. 205-211.

Watterworth, H.E., Lawson, R.H. and Kahn, R.P. (1974). Purification, electron microscopy, and serology of Dioscorea latent virus. Journal of Agriculture of the University of Puerto Rico 58:351-357.

Withers, L.A. (1991). Crop strategies for roots and tubers: potato- A model for refinement, Yam- a problem for development. In Workshop on Conservation of Plant Genetic Resources. Becker B. Ed., Bonn. ATSAF/IBPGR, pp. 11-14. 